\title{
Subjects matter: a survey of public opinions about a large genetic cohort study
}

David Kaufman, PhD, Juli Murphy, MS, Joan Scott, MS, CGC, and Kathy Hudson, PhD

\begin{abstract}
Purpose: Cohort studies investigating genes, environment, and lifestyle require large study populations. To recruit and retain participants, it is important to understand the relative significance of influences on people's motivation to participate. To this end, 4659 Americans were surveyed about support for and willingness to participate in a proposed large cohort study. Methods: An online survey of US adults was conducted between December 2007 and January 2008. To measure the influence of study burden, compensation and receipt of individual research results on willingness to participate, respondents were randomized to one of eight different study scenarios. Results: Most respondents (84\%) supported the study, and $60 \%$ would participate. Returning research results (odds ratio $=1.6$, 95\% confidence interval 1.3-1.8) and increasing compensation from $\$ 50$ to $\$ 200$ (odds ratio $=1.5,95 \%$ confidence interval 1.2-1.7) were associated with increased willingness to participate. Decreasing study burden was less important (odds ratio $=1.2,95 \%$ confidence interval 1.0-1.4). Three in four respondents would be less likely to participate without the return of research results. Support and willingness varied little among demographic groups; variation in influences of the three factors on willingness was observed. Conclusion: Widespread support exists in the general public for a large national cohort study. Providing individual research results is a strong motivation to participate; compensating participants $\$ 200$ may increase participation a similar amount. Incentives, recruitment, and return of results could be tailored to demographics groups' interests. Genet Med 2008:10(11): 831-839.
\end{abstract}

Key Words: public opinion, biobank, genetic research, research results, public engagement

Large, prospective cohort studies using banked DNA samples are becoming a standard research tool to examine the effects and interactions of genes, environment, and lifestyle. ${ }^{1-6}$ Various approaches are used to collect DNA, biological samples, and information on health and environmental exposures. Participants are followed over time, and genotype, lifestyle, and exposure data compared among those who do and do not develop a given disease. Although they are labor-, time-, and capital-intensive, 7,8 these studies are gaining favor because of the statistical power that large sample sizes provide to detect small biological effects. ${ }^{7,9,10}$ Both public ${ }^{6,11}$ and private ${ }^{4,12}$ cohort studies and biobanks are being created. Genetic analyses are being incorporated into existing cohort studies as genotyping and computational tools become more accessible. ${ }^{11,13,14} \mathrm{At}$ least one commercial company selling direct-to-consumer ge-

From the Genetics and Public Policy Center, Johns Hopkins University, Washington DC. David Kaufman, Genetics and Public Policy Center, 1717 Massachusetts Avenue, NW, Suite 530, Washington DC 20036. E-mail: dkaufma2@jhu.edu.

Disclosure: The authors declare no conflict of interest.

Supplementary materials are available via the ArticlePlus feature at www.geneticsinmedicine. org. Please go to the November issue and click on the ArticlePlus link posted with the article in the Table of Contents to view this material.

Submitted for publication July 17, 2008.

Accepted for publication August 21, 2008.

DOI: 10.1097/GIM.0b013e31818bb3ab netic tests has launched a research component to bank customers' DNA and track their health over time. ${ }^{8}$

The National Institutes of Health has funded several small and medium-sized cohort studies that incorporate genetic analyses. The National Human Genome Research Institute is contemplating the creation of a new, large prospective observational study on the scale of the UK Biobank to enable researchers to examine interactions between genetic and nongenetic risk factors that contribute to common complex diseases. ${ }^{15,16}$ A 2004 draft study design ${ }^{9}$ recommended recruitment of a nationwide, representative sample of at least 500,000 people. During a baseline examination, researchers would collect biospecimens and request participants' consent to access their medical records. Laboratories would isolate and genotype DNA for a set of genome-wide markers. Data processing would de-identify samples and information, while retaining a link to participants to allow for prospective follow-up of health outcomes. Although the draft study design was not specific, participants might be asked to monitor their diet, physical activity, environmental exposures, or biomarker levels, and researchers might collect samples from participants' homes, workplaces, or neighborhoods. The study would make coded data available to the broader scientific community for analysis of gene-environment interactions.

The study would provide participants few direct medical benefits. Participants would receive clinically relevant results 
of initial exams. Whether the study would return individual research results-including genetic test results and information about nongenetic exposures-to participants is undecided.

The proposed study, like others of its kind, is both logistically complex and expensive. ${ }^{15}$ Its success would depend in part on public acceptance. A sizeable sample representative of the larger US population would need to be recruited and retained. ${ }^{17}$ Funders and the public are unlikely to commit to a large-scale effort without evidence that the study can meet recruitment goals and successfully collect, protect, and analyze data.

To measure public support for such a study, and to identify and prioritize public concerns and issues that must be addressed before the study could proceed, a survey of a representative sample of 4659 Americans was conducted as part of a larger public engagement effort. The survey provided quantitative measures of the public's support for the study and willingness to participate, the influences of three components of study design on peoples' decision to participate, and how support, willingness, and influences on participation vary by demographic characteristics.

\section{METHODS}

\section{Survey methods}

A 177-item online survey, qualified by The Johns Hopkins University Institutional Review Board as exempt (Application \#NA-00014533), was developed to collect data on public opinions about a national cohort study proposed by the National Human Genome Research Institute. Based on focus groups conducted in 2007 in five cities, ${ }^{18}$ a survey instrument was drafted that comprised four main sections. Respondents answered questions on health matters and general beliefs and then were shown a 3-minute video developed for this project to describe the goals and design of the proposed cohort study. ${ }^{19}$ Respondents who could not view the video were shown a written description of the cohort study that matched the video script and a schematic diagram of major study components. A definition of individual research results was provided. Hyper- links to the study description and the definition of research results were inserted throughout the survey instrument (see Supplementary Materials).

Following the video, participants were asked questions about the cohort study. Included were a series of questions where half of respondents were asked if they wanted to know about a "genetic risk factor for" a disease or condition and half were asked if they wanted to know if they "were at increased risk for" that disease or condition.

Finally, respondents were shown one of eight study design scenarios selected at random and asked whether they would participate in the cohort study. The eight scenarios varied with respect to three factors: study burden (low and high), return of individual research results (returned or not), and compensation for participation ( $\$ 50$ or $\$ 200$ ). The exact wording of each version of the three factors is found in Table 1.

A large pilot survey $(n=480$; response rate $63.4 \%)$ was fielded between November 27 and December 7, 2007, to evaluate the study scenarios, length, logic, skip patterns, and wording. In the pilot, no difference was observed in respondents' willingness to participate between the "high burden" and "low burden" scenarios (see Supplementary Materials for original scenarios). Thus more requirements were added to the highburden option. Median time to complete the pilot survey was 41 minutes, so the instrument was shortened to the maximum acceptable length of 30 minutes.

Sample selection and online administration of the survey was managed by Knowledge Networks $(\mathrm{KN}) .^{20}$ During the field period, 8,735 potential respondents 18 years and older were randomly sampled from $\mathrm{KN}^{\prime}$ 's web-enabled master panel of 43,000 US residents; the goal was 4,910 respondents, including a random sample of 3,700 and oversamples of 480 black non-Hispanics, 480 Hispanics, and 250 people living outside of metropolitan statistical areas. KN selects its master panel using list-assisted random digit dialing to provide a probabilitybased sample to from which draw. Weights corresponding to US census demographic benchmarks were calculated for this survey sample to account for the oversamples and to reduce bias from sampling error. A separate set of weights was created

Table 1

Exact wording of study design factors used to define eight study scenarios

\begin{tabular}{ll}
\hline Study design factor & Exact wording
\end{tabular}

Study burden

Let's say the study is going forward and you were invited to participate. At the beginning of the study, you would be asked to travel to a local health clinic for one half day of exams. You would provide samples (blood, urine, etc.) for laboratory tests and fill out questionnaires on your health, diet, and lifestyle. (In addition, you would be asked to complete a health assessment questionnaire once a year for the next 10 years) or (Researchers would come to your home to collect environmental samples and to place a device to monitor air quality. You would be asked keep a diet and exercise journal for 1 week and to complete a health assessment questionnaire once a year for the next 10 years).

Return of results

You would receive results from your initial physical examination and laboratory tests. You would also receive general research findings from the study. (However, you would not be given any individual research results) or (You could also find out your individual research results if you wanted to).

Compensation

The study would reimburse you for the cost of any travel to and from the initial examination. (You would receive $\$ 50$ to compensate you for time spent at the initial examination) or (You would receive $\$ 200$ to compensate you for time spent at the initial examination, and an additional $\$ 20$ for each completed health assessment questionnaire). 
for each of the oversampled groups to enable analyses within each of these groups.

The main survey was fielded online between December 14, 2007 and January 31, 2008. Potential participants were emailed an invitation to participate, and nonresponders received an email reminder after 3 days. Nonresponders in the oversamples received two additional email reminders. Most participants received the equivalent of $\$ 5$ for their time. Toward the end of the field period, the incentive was increased to $\$ 10$ to maximize the number of responses from oversampled groups. After survey data were collected, prebanked information previously collected by $\mathrm{KN}$ on panel members' demographics and backgrounds was added to the data set.

\section{Analysis methods}

Data were recoded, sorted, and prepared for analysis using SPSS software. ${ }^{21}$ Support for the study and willingness to participate were both measured using four-point Likert scales; two binary variables (support/do not support and willing/not willing) were created for analysis from these scales. Data were analyzed using the SUDAAN software package, ${ }^{22,23}$ which employs Taylor series linearization estimation of variance to correct for the survey sampling scheme when judging hypothesis test results. Data were corrected using the "STRWOR" (stratified without replacement) design option. Multiple logistic regression was used to examine demographic factors associated with support and participation, and the association of the study design factors with willingness to participate, adjusting for demographics. Analyses that included the entire sample were weighted to US census demographic benchmarks. Analyses within or among races and ethnic groups, or urban and rural participants, used the alternate weights calculated for these oversampled groups.

\section{RESULTS}

In total, 7978 people were contacted to take the survey and 4659 provided valid responses, for an overall response rate of $58.4 \%$. It should be noted that to be eligible for the $\mathrm{KN}$ panel (and thus the survey), people had to respond to a phone call from KNs and provide their baseline demographic information. This process gives potential respondents multiple opportunities to refuse and could be interpreted as reducing the overall response rate, but has been shown to produce survey samples that are unbiased with respect to demographics or attitudes. ${ }^{20}$

The margin of error on opinion estimates based on the sample of 4659 is $\pm 1.6 \%$ after weighting the data and correcting for sampling design. The margin of error within a group that was shown the same scenario is $\pm 4.0 \%$. A total of $69 \%$ of respondents were able to view the video explaining the cohort study; the remaining $31 \%$ were shown the written description and a schematic diagram to explain the study. Participants living in rural areas, those with lower household incomes, African Americans, and Hispanics were significantly less likely to have successfully viewed the video.
Demographic characteristics of the surveyed population are found in Table 2. Both weighted and unweighted demographic distributions of the sample were comparable to US 2000 census figures (comparisons to US 2000 census data can be found in the Supplementary Material).

\section{General support for the cohort study}

Immediately after viewing the description of the cohort study participants were asked "Based on what you just learned, do you think the study should be done?" Eighty-four percent felt the study definitely (25\%) or probably (59\%) should be done, whereas smaller numbers said probably not $(12 \%)$ or definitely not (4\%). This high level of support was observed across all demographic groups (Table 2). With the exceptions of participants who had not graduated from high school and American Indians and Alaska Natives, $>80 \%$ of every demographic group supported the study. Adjusting for other factors in Table 2 and success watching the video, no significant differences in support were observed between Hispanics, white non-Hispanics, black non-Hispanics, and Asians. American Indians and Alaska Natives were less likely than white nonHispanics to support the study $(P=0.0004)$, whereas nonHispanic respondents of two or more races were significantly more likely to support the study $(P=0.04)$.

Income, education, and viewing the video also were statistically significant predictors of support for the study in a multiple logistic regression treating support for the cohort study as a binary independent variable (definitely + probably versus definitely not + probably not). Both annual household income $>\$ 75,000$ and possession of a Bachelor's degree were independently associated with support for the study in a multiple logistic regression adjusting for other demographic covariates. However, in both cases, the magnitude of the differences was small (Table 2). Support for the study was also significantly higher among participants who were able to watch the video describing the study compared with those who read the study description (86 vs. $80 \%$; adjusted odds ratio $[\mathrm{OR}]=1.6,95 \%$ confidence interval $[\mathrm{CI}] 1.3-2.0, P=0.0001$ ).

\section{Stated willingness to participate in the cohort study}

At the conclusion of the survey, each participant was selected randomly to view one of eight different study scenarios. The survey then asked "Would you participate in the cohort study if you were asked?" For all scenarios combined, $60 \%$ of participants said that they definitely (16\%) or probably (44\%) would participate given the scenario they viewed. As with general support for the study, willingness to participate did not vary a great deal between demographic groups (Table 2). Majorities $(\geq 55 \%)$ in all demographic groups said they would definitely or probably participate if asked.

However, in a multiple logistic regression that treated responses to the participation question as a binary dependent variable, some small but statistically significant differences were observed. Hispanics, black non-Hispanics, Asians, American Indians and Alaska Natives, and white non-Hispanics all were equally likely to say they would participate. Non- 
Table 2

Opinions on the proposed cohort study, by demographic group

\begin{tabular}{|c|c|c|c|c|}
\hline Demographic group & Unweighted $\mathrm{N}$ & Weighted percent & $\begin{array}{l}\text { \% Who said study probably or } \\
\text { definitely should be done }\end{array}$ & $\begin{array}{l}\% \text { Who would probably or } \\
\text { definitely participate }\end{array}$ \\
\hline Total & 4659 & 100 & 84 & 60 \\
\hline Men & 2247 & 48 & 83 & 60 \\
\hline Women & 2412 & 52 & 85 & 60 \\
\hline White non-Hispanic & 2798 & 70 & 85 & 60 \\
\hline Black non-Hispanic & 774 & 11 & 81 & 57 \\
\hline Hispanic (all races) & 867 & 12 & 84 & 60 \\
\hline American Indian/Alaskan Native (non-Hispanic) & 35 & 1 & $65^{a}$ & 63 \\
\hline Asian/Pacific Islander (non-Hispanic) & 71 & 2 & 87 & 65 \\
\hline $2+$ races (non-Hispanic) & 114 & 3 & $92^{b}$ & $71^{b}$ \\
\hline Age 18-29 & 838 & 22 & 84 & $64^{c}$ \\
\hline Age $30-44$ & 1207 & 27 & 84 & 59 \\
\hline Age 45-64 & 1791 & 35 & 86 & 64 \\
\hline Age $65+$ & 823 & 17 & 82 & 55 \\
\hline Household income under $\$ 25,000$ & 959 & 24 & 82 & 59 \\
\hline$\$ 25,000-\$ 49,999$ & 1499 & 31 & 83 & 57 \\
\hline$\$ 50,000-\$ 74,999$ & 1071 & 21 & 84 & 60 \\
\hline Over $\$ 75,000$ & 1130 & 21 & $89^{d}$ & $67^{d}$ \\
\hline$<$ High school & 502 & 14 & 79 & 58 \\
\hline High school & 1380 & 32 & 84 & 55 \\
\hline Some college & 1406 & 28 & 82 & 61 \\
\hline Bachelor's degree & 1371 & 27 & $88^{e}$ & $67^{e}$ \\
\hline Metro MSA & 3773 & 84 & 85 & 60 \\
\hline Non-metro MSA & 886 & 16 & 84 & 58 \\
\hline Northeast & 787 & 18 & 83 & 57 \\
\hline Midwest & 1078 & 21 & 84 & 59 \\
\hline South & 1672 & 38 & 84 & 59 \\
\hline West & 1122 & 23 & 84 & $64^{f}$ \\
\hline
\end{tabular}

In multivariate analyses:

${ }^{a} \mathrm{OR}$ comparing AI/AN to non-Hispanic whites $=0.26 ; 95 \%$ CI $0.10-0.64, P=0.004$.

${ }^{b} \mathrm{OR}$ comparing respondents of multiple races or other races to non-Hispanic whites: study support OR $=2.11,95 \%$ CI 1.03-4.34, $P=0.04$; participation OR $=2.24$, $95 \%$ CI $1.42-3.55, P=0.0005$.

${ }^{c}$ OR comparing respondents under age 30 to older participants $=1.24 ; 95 \%$ CI $1.02-1.52, P=0.02$.

${ }^{d} \mathrm{OR}$ comparing respondents with household incomes $>\$ 75,000$ to those with incomes under $\$ 75,000$ : study support OR $=1.45 ; 95 \%$ CI $1.10-1.91, P=0.008$; participation $\mathrm{OR}=1.35,95 \%$ CI $1.11-1.62, P=0.002$.

${ }^{e} \mathrm{OR}$ comparing respondents with bachelor's degrees to those with less education: study support $\mathrm{OR}=1.34 ; 95 \% \mathrm{CI} 1.05-1.72, P=0.02$; participation OR $=1.35$; $95 \%$ CI $1.14-1.61, P=0.0007$.

${ }^{f} \mathrm{OR}$ comparing respondents living in the western region of the United States to those in other regions: OR $=1.20 ; 95 \%$ CI $1.00-1.45, P=0.05$.

MSA, metropolitan statistical area.

Hispanic respondents of two or more races not specifically listed in Table 2 were more likely to say they would participate, adjusting for the other variables in Table 2. An annual household income of $>\$ 75,000$ and a Bachelor's degree also were independently associated with increased willingness to participate in the cohort study (Table 2). Younger respondents were significantly more likely to say that they would participate. Additionally, people who lived in the Western region of the United States were more likely than people in other areas of the country to say they would participate (Table 2). Willingness to participate was not related to respondents' viewing the video description of the cohort study.

Support for the study was strongly associated with people's willingness to participate. Among those who thought the study should definitely or probably be done, 85 and $60 \%$ respectively 
Table 3

Responses to question about whether people would participate in the cohort study if asked, by study scenario

\begin{tabular}{|c|c|c|c|c|c|c|c|}
\hline \multicolumn{3}{|c|}{ Study component } & \multicolumn{5}{|c|}{ Percent that would participate if asked } \\
\hline $\begin{array}{l}\text { Individual research } \\
\text { results returned }\end{array}$ & $\begin{array}{c}\text { Level of } \\
\text { compensation }\end{array}$ & $\begin{array}{l}\text { Study } \\
\text { burden }\end{array}$ & $\begin{array}{l}\text { Definitely } \\
\text { yes }(\%)\end{array}$ & $\begin{array}{l}\text { Probably } \\
\text { yes }(\%)\end{array}$ & $\begin{array}{l}\text { Probably } \\
\text { no }(\%)\end{array}$ & $\begin{array}{l}\text { Definitely } \\
\text { no (\%) }\end{array}$ & $\begin{array}{l}\text { Total "yes" } \\
(\%)\end{array}$ \\
\hline Yes & $\$ 200$ & Low & 22 & 51 & 18 & 9 & 73 \\
\hline Yes & $\$ 200$ & High & 20 & 48 & 22 & 10 & 68 \\
\hline Yes & $\$ 50$ & Low & 18 & 45 & 26 & 11 & 63 \\
\hline No & $\$ 200$ & Low & 17 & 45 & 22 & 16 & 61 \\
\hline Yes & $\$ 50$ & High & 16 & 41 & 20 & 13 & 57 \\
\hline No & $\$ 200$ & High & 14 & 42 & 27 & 17 & 56 \\
\hline No & $\$ 50$ & Low & 11 & 41 & 30 & 18 & 52 \\
\hline No & $\$ 50$ & High & 9 & 42 & 32 & 17 & 51 \\
\hline Total (\%) & & & 16 & 44 & 26 & 14 & 60 \\
\hline
\end{tabular}

Some totals may not sum to $100 \%$ due to rounding errors.

said they would participate, whereas people who thought the study probably or definitely should not be done were less likely to participate (25 and 11\% willing respectively; overall adjusted $P<0.0001)$.

\section{Associations of study design factors with willingness to participate}

Although majorities said they would probably or definitely participate under all eight scenarios, the fraction ranged from 51 to $73 \%$ (Table 3). Respondents were most willing to participate in a low-burden study that offered higher compensation and returned research results, whereas the least popular scenario required more of participants, provided less money and would not give participants their research results.

Offering return of individual research results was associated with the largest positive increase in participation, followed closely by increasing compensation. A lower anticipated burden of the study was associated with a smaller, but still significant increase. For example, Table 3 shows that adding the return of research results to the least popular study design was associated with a $6 \%$ increase in willingness to participate. Offering \$200 compensation, in contrast, was associated with a $5 \%$ increase in willingness to participate, whereas a lower anticipated study burden was associated only with a modest increase (1\%). Similarly, comparing the most popular scenario to those where one of the three study benefits had been removed, the largest change was observed when research results are not returned (Table 3 ). In a multiple logistic regression adjusting for income, education, geographic region, race and ethnicity, and age, offering individual research results was most strongly associated with respondents' willingness to participate $(\mathrm{OR}=1.6,95 \%$ CI $1.3-1.8 ; P<0.0001)$, followed by increased compensation $(\mathrm{OR}=1.5,95 \% \mathrm{CI}$ $1.2-1.7 ; P<0.0001)$, and lower burden $(\mathrm{OR}=1.2,95 \% \mathrm{CI}$ $1.0-1.4 ; P=0.01)$.

Responses to questions asked earlier in the survey reinforce the significance of receiving individual research results and other health information. Three in four respondents said that if individual research results were not made available, they would be less willing to participate. When asked to rank a list of possible benefits of participating, the most important was "receiving information about my health"; $94 \%$ said this would be very $(66 \%)$ or somewhat $(28 \%)$ important in their decision to participate. By comparison, 75\% said monetary compensation was very $(34 \%)$ or somewhat important $(41 \%)$.

Nine in ten respondents agreed that they would want to know all of their individual research results, and 91\% wanted their individual research results about health risks "even if there was nothing [they] could do about them." Nearly all respondents would want to know if researchers found they "had a genetic risk factor" (96\%) or "were at increased risk" (95\%) for "a treatable condition like severe asthma." Similarly, nearly all also would want to know if they had a genetic risk factor (95\%) or were at increased risk (96\%) for a "bad reaction to certain types of medicine" or had a genetic risk factor $(88 \%)$ or an increased risk $(90 \%)$ for "an untreatable disease like Alzheimer.”

In contrast, $8 \%$ would not want their research results because it would be "too much information," $17 \%$ would not want results predicting future illness because the information would worry them, and 7\% were "not that interested" in results.

\section{Interaction between study design factors}

For all three of the study design factors, the increase in willingness to participate associated with each "beneficial" individual factor (lower burden, \$200, return of results) was greater when at least one of the other beneficial factors was offered as well (Table 4). The first row of the table shows the increased odds that respondents say they will participate when one of the beneficial versions of a study factor is added to the scenario with none of the beneficial factors - for example, adding return of results to the minimal study scenario increases the 
Table 4

Increase in odds of intent to participate accompanying the addition of study benefits to different scenarios

Increased odds of answering "Probably or definitely participate" associated with adding a

"benefit" to a scenario (odds ratio and 95\% confidence interval)

\begin{tabular}{|c|c|c|c|}
\hline \multirow[b]{3}{*}{ Scenario } & \multirow{2}{*}{\multicolumn{3}{|c|}{ Benefit added to scenario }} \\
\hline & & & \\
\hline & $\begin{array}{l}\text { Return of } \\
\text { results }\end{array}$ & $\$ 200$ & $\begin{array}{l}\text { Lower } \\
\text { burden }\end{array}$ \\
\hline $\begin{array}{l}\$ 50, \text { No results, } \\
\text { High burden }\end{array}$ & $\begin{array}{c}1.29 \\
(1.02-1.63)\end{array}$ & $\begin{array}{c}1.24 \\
(0.98-1.57)\end{array}$ & $\begin{array}{c}1.06 \\
(0.84-1.34)\end{array}$ \\
\hline $\begin{array}{l}\$ 50 \text {, No results, } \\
\text { Lower burden }\end{array}$ & $\begin{array}{c}1.57 \\
(1.22-2.01)\end{array}$ & $\begin{array}{c}1.46 \\
(1.15-1.86)\end{array}$ & NA \\
\hline $\begin{array}{l}\$ 200, \text { No results, } \\
\text { High burden }\end{array}$ & $\begin{array}{c}1.66 \\
(1.30-2.13)\end{array}$ & NA & $\begin{array}{c}1.24 \\
(0.98-1.59)\end{array}$ \\
\hline $\begin{array}{l}\$ 50 \text {, Results returned, } \\
\text { High burden }\end{array}$ & NA & $\begin{array}{c}1.60 \\
(1.26-2.04)\end{array}$ & $\begin{array}{c}1.20 \\
(0.94-1.52)\end{array}$ \\
\hline $\begin{array}{l}\$ 200, \text { No results, } \\
\text { Lower burden }\end{array}$ & $\begin{array}{c}1.70 \\
(1.31-2.19)\end{array}$ & NA & NA \\
\hline $\begin{array}{l}\$ 50 \text {, Results returned, } \\
\text { Lower burden }\end{array}$ & NA & $\begin{array}{c}1.58 \\
(1.21-2.05)\end{array}$ & NA \\
\hline $\begin{array}{l}\$ 200 \text {, Results returned, } \\
\text { High burden }\end{array}$ & NA & NA & $\begin{array}{c}1.27 \\
(0.98-1.64)\end{array}$ \\
\hline
\end{tabular}

odds of participating by a factor of 1.29 . The remaining rows show the change associated with adding each of the beneficial factors to a scenario where at least one of the other benefits is also offered. The increased odds of participation associated with providing research results is significantly higher (1.57, $1.66,1.70$ respectively) when research results are added to a scenario that offers $\$ 200$, an easier study protocol, or both. A similar pattern is observed for both compensation and study burden.

\section{Associations of study design factors with willingness to participate, by demographic group}

Differences between demographic groups in associations of the three factors with willingness to participate are shown in Table 5. All ORs are adjusted for age, education, household income, and geographic region. Although there are several exceptions, many strata follow the same pattern as the overall dataset: returning results is associated with the largest change in attitudes about participation, followed closely by increased compensation, whereas decreasing study burden is associated with a small or negligible change.

There were, however, interesting differences between groups. For example, increased compensation was the strongest factor influencing participants with household incomes $<\$ 25,000$ and those earning $>\$ 75,000$. A lower study burden was significant among women but not men, and among rural respondents but not urban ones.

\section{DISCUSSION}

\section{Support for the proposed cohort study and willingness to participate}

The survey data reveal widespread support among the US public for the proposed cohort study. Other surveys of general populations and potential study participants have shown similar results. In a random sample of 1384 Québécois, 75\% had "a lot of enthusiasm" or "a certain enthusiasm" for a similar study of genes and environment. ${ }^{24}$ Surveys in Sweden ${ }^{25}$ and Iceland ${ }^{26}$ found that 71 and $81 \%$ of people respectively supported creation of a biobank for genetic research. In the United States, a survey of Vanderbilt patients found $88 \%$ supported a new biobank, ${ }^{27}$ and $95 \%$ of participants in a case-control study of colon cancer genetics supported longitudinal genetic research. ${ }^{28}$

In our study, the overall fraction who said they would be willing to participate-60\%-falls within the range of $38-78 \%$ support observed in other surveys of the American public about donating blood or DNA to a future biobank or cohort study. ${ }^{29-34}$ A 2001 survey of the US public showed 53\% would "donate blood for research to find genes that affect peoples' health." ${ }^{29}$ People already enrolled in research have participated in new genetic studies at even higher rates. ${ }^{35-38}$ For example, at least $85 \%$ of participants in the ongoing NHANES study consented to the use of donated samples for genetic research. ${ }^{14,36}$

In our survey, the levels of both support and willingness to participate were consistent across demographic groups, including most races and ethnicities. This finding contrasts with several studies showing lower support for or participation in genetic research among African Americans. 14,27-29,39,40

American Indians and Alaska Natives in our survey were significantly less likely than other races and ethnic groups to support the proposed study (65\%), but were as likely as others (63\%) to participate. This measure of willingness to participate is consistent with a 2006 study that found that $64 \%$ of an urban American Indian and Alaskan Native sample would participate in a hypothetical genetic study. ${ }^{31}$ The success of federallyfunded genetic cohort studies specifically targeted at American Indians and Alaska Natives indicate that recruiting in these populations is possible, but may require high levels of community involvement. ${ }^{13,41}$

Viewing the video was a significant predictor of overall support for the study but not of people's willingness to participate. Inflection, tone, and images in the audio and video may have given more concrete meaning to the words and increased understanding, may have lent a measure of credibility to the study description, or may have created a persuasive bias. However, though the difference in support for the study was statistically significant, it was not large.

\section{Influences on participation: research results, compensation, and study burden}

In this study and others, ${ }^{38,42} 90 \%$ of survey respondents wanted their genetic or risk information even when there was nothing that currently could be done with the information. 
Table 5

Effect of return of results, incentive amount, and study burden on attitudes about participating in the proposed cohort study

\begin{tabular}{|c|c|c|c|c|c|c|c|c|c|}
\hline \multirow[b]{2}{*}{ Demographic group } & \multicolumn{3}{|c|}{$\begin{array}{l}\text { Return of research results } \\
\text { \% Who definitely or probably would } \\
\text { participate if they received: }\end{array}$} & \multicolumn{3}{|c|}{$\begin{array}{l}\text { Level of compensation } \\
\% \text { Who definitely or } \\
\text { probably would } \\
\text { participate if they } \\
\text { received: }\end{array}$} & \multicolumn{3}{|c|}{$\begin{array}{c}\text { Study burden } \\
\text { \% Who definitely or probably } \\
\text { would participate under a } \\
\text { study design with: }\end{array}$} \\
\hline & $\begin{array}{l}\text { Indiv. Res. } \\
\text { results }\end{array}$ & $\begin{array}{l}\text { No Indiv. } \\
\text { Res. results }\end{array}$ & $\begin{array}{l}\text { Odds } \\
\text { ratio }\end{array}$ & $\$ 200$ & $\$ 50$ & $\begin{array}{l}\text { Odds } \\
\text { ratio }\end{array}$ & $\begin{array}{l}\text { Low } \\
\text { burden }\end{array}$ & $\begin{array}{l}\text { High } \\
\text { burden }\end{array}$ & $\begin{array}{l}\text { Odds } \\
\text { ratio }\end{array}$ \\
\hline Total & $65 \%$ & $55 \%$ & $1.56^{a}$ & $65 \%$ & $56 \%$ & $1.45^{a}$ & $63 \%$ & $58 \%$ & $1.20^{b}$ \\
\hline Men & $66 \%$ & $55 \%$ & $1.63^{a}$ & $65 \%$ & $55 \%$ & $1.52^{a}$ & $61 \%$ & $59 \%$ & 1.10 \\
\hline Women & 65 & 55 & $1.51^{a}$ & 64 & 56 & $1.41^{b}$ & 64 & 57 & $1.31^{b}$ \\
\hline White non-Hispanic & 64 & 55 & $1.49^{a}$ & 63 & 56 & $1.33^{b}$ & 63 & 57 & $1.28^{b}$ \\
\hline Black non-Hispanic & 59 & 54 & 1.19 & 62 & 51 & $1.59^{b}$ & 56 & 57 & 1.02 \\
\hline Hispanic (all races) & 73 & 49 & $3.61^{a}$ & 69 & 50 & $2.79^{a}$ & 61 & 59 & 1.05 \\
\hline American Indian/Alaskan Native (non-Hispanic) & 60 & 67 & 0.52 & 65 & 62 & 1.02 & 61 & 64 & 0.76 \\
\hline Asian/Pacific Islander (non-Hispanic) & 71 & 65 & 1.14 & 69 & 69 & 0.98 & 74 & 63 & 1.51 \\
\hline $2+$ races (non-Hispanic) & 79 & 76 & 1.12 & 84 & 72 & 2.24 & 74 & 82 & 0.64 \\
\hline Age $18-29$ & 71 & 58 & $1.63^{b}$ & 71 & 57 & $1.78^{b}$ & 62 & 66 & 0.78 \\
\hline Age $30-44$ & 66 & 51 & $1.88^{a}$ & 63 & 54 & $1.44^{b}$ & 62 & 55 & 1.29 \\
\hline Age 45-59 & 67 & 60 & $1.33^{b}$ & 68 & 59 & $1.43^{b}$ & 68 & 60 & 1.37 \\
\hline Age $60+$ & 58 & 51 & $1.37^{b}$ & 58 & 52 & 1.29 & 58 & 52 & $1.30^{b}$ \\
\hline Under $\$ 25,000$ & 63 & 56 & 1.25 & 66 & 52 & $1.82^{a}$ & 60 & 59 & 1.05 \\
\hline$\$ 25,000-\$ 49,999$ & 64 & 50 & $1.83^{a}$ & 61 & 52 & $1.46^{b}$ & 58 & 55 & 1.15 \\
\hline$\$ 50,000-\$ 74,999$ & 66 & 53 & $1.77^{a}$ & 61 & 58 & 1.09 & 64 & 55 & $1.45^{b}$ \\
\hline Over $\$ 75,000$ & 70 & 65 & 1.32 & 72 & 63 & $1.56^{a}$ & 70 & 64 & 1.32 \\
\hline$<$ High school & 60 & 54 & 1.13 & 67 & 43 & $2.34^{a}$ & 57 & 56 & 1.10 \\
\hline High school & 61 & 49 & $1.55^{a}$ & 57 & 52 & $1.36^{b}$ & 55 & 54 & 1.04 \\
\hline Some college & 68 & 54 & $1.71^{a}$ & 66 & 57 & $1.41^{b}$ & 66 & 57 & $1.41^{b}$ \\
\hline Bachelor's degree & 72 & 62 & $1.59^{b}$ & 70 & 63 & $1.41^{b}$ & 70 & 64 & $1.33^{b}$ \\
\hline Metro MSA & 66 & 55 & $1.63^{a}$ & 65 & 56 & $1.47^{a}$ & 62 & 59 & 1.12 \\
\hline Non-metro MSA & 62 & 53 & 1.26 & 61 & 54 & 1.34 & 64 & 51 & $1.56^{b}$ \\
\hline Northeast & 64 & 51 & $1.68^{b}$ & 64 & 51 & $1.65^{b}$ & 60 & 55 & 1.26 \\
\hline Midwest & 64 & 54 & $1.65^{a}$ & 63 & 55 & $1.48^{b}$ & 64 & 54 & $1.55^{b}$ \\
\hline South & 63 & 56 & $1.32^{b}$ & 65 & 54 & $1.61^{a}$ & 61 & 59 & 1.08 \\
\hline West & 71 & 58 & $1.82^{a}$ & 66 & 62 & 1.20 & 65 & 63 & 1.11 \\
\hline
\end{tabular}

${ }^{a}$ Odds ratio is significant with $P \leq 0.001$.

${ }^{b}$ Odds ratio is significant with $0.001<P<0.05$.

MSA, metropolitan statistical area.

Some critics of returning individual genetic research results to research participants cite a version of the problem of "therapeutic misconception" 43 - that participants will confuse researchers and research data with clinicians and clinical dataand that individual results generally should not be returned. ${ }^{44,45}$ Research data may be of little or no proven clinical value, and efforts to interpret such results could lead research participants down inappropriate or dangerous clinical pathways. ${ }^{45}$ Although bioethicists, researchers, patient advo- cates, and institutional review boards rightly will debate what information should be returned to participants, a large majority of the public simply wanted access to all research results, regardless of the immediate utility of the data. This suggests that more detailed research to explore what the public understands and believes about individual research results may be warranted.

Public eagerness for genetic information is unsurprising in an environment where genetic research is widely believed to be 
beneficial, and where genetic tests are sold directly to consumers. ${ }^{46,47}$ Other studies that have examined public views have also shown wide support for the return of research results from biobanked samples. ${ }^{24,25,38,42,48-50}$ For example, in a study of healthy elderly participants in an Alzheimer study, 89\% wanted their research results if the sample were used for other studies, regardless of the clinical significance. ${ }^{38}$ In a survey of parents of pediatric oncology patients, $95 \%$ said they had a strong or very strong right to receive study results whether the findings were "good," "bad," or "neutral."42 This eagerness suggests that researchers may have to look for practical ways to return results, and abandon the paternalistic stance of protecting people from their research data. Further research may be warranted to determine whether the passage of the Genetic Information Nondiscrimination Act in 2008 has influenced researchers' concerns or participants' desires for individual genetic data from research studies.

With that said, many large research projects continue to successfully enroll volunteers in genetic protocols that will not return individual results. ${ }^{3,14,27,51,52}$ In a study of consent to genetic research in the NHANES cohort, the authors interpreted the high participation rate as a demonstration of "willingness to agree to genetic research even without the incentive of determining their own susceptibility for disease." ${ }^{14}$ In our survey, $13 \%$ said they definitely and $42 \%$ probably would participate in the planned cohort study in the scenarios where research results were not returned.

Although returning research results provided the strongest incentive to participate in this survey, increased compensation had a similarly large effect. Some researchers feel that financial compensation is a form of undue inducement to participate in biomedical studies, ${ }^{53}$ especially when recruiting in low-income populations. ${ }^{54}$ Others feel that compensation is simply one of many legitimate benefits in the transaction of consent and participation..$^{55}$ Our observation that increasing compensation was the strongest factor influencing willingness to participate among people earning $\$ 75,000$ or more per year and those earning $<\$ 25,000$ suggests that $\$ 200$ compensation might not disproportionately influence lower-income populations to join the proposed study. This conclusion could be strengthened by comparing willingness in scenarios offering no monetary compensation.

The variations in study burden that we presented had only a modest influence on willingness to participate. We chose a high-burden scenario based on realistic options that the proposed study might employ that require more data collection efforts by participants and in-home measurements by study staff. However, the extra burdens did not change physical risks to participants. Thus our conclusion about study burden is limited to the statement that moderate increases in data collection efforts that do not incur additional physical or psychological risk will not greatly affect people's willingness to participate.

Survey methods similar to the one used here previously have been used to compare the effects of factors including varied reimbursement, randomization to a treatment or placebo arm, and different chances of adverse effects on willingness to participate in clinical studies. ${ }^{56-59}$ However, our study is unique in its comparison of the magnitude of effects of study burden, compensation, and the return of results on people's potential willingness to participate in longitudinal genetic research.

What members of the general public expect in return for participation in a prospective cohort study of genes, environment, and lifestyle should be taken into consideration, but must be balanced against the researchers' recruitment benchmarks and available resources. ${ }^{55}$ The least beneficial scenario that we tested may provide enough benefit to volunteers to reach some or all of the proposed study's recruitment goals. However, if any two of the three "positive" factors were offered to participants, the number of people who said they would definitely participate doubled. The costs of making the study more attractive to people could be more than offset by reductions in recruiting time and expense if half as many contacts and invitations were required to meet recruitment goals. Additionally, willingness to continue participating through the life of the cohort study must accompany initial enrollment. It may be that providing even limited individual research results or graduated incentives over time could increase retention and recruitment.

It should be noted that people's responses on a survey about their willingness to participate in a hypothetical study should not be construed as estimates of the actual percentage of people who would participate. Survey responses about future behavior do not always correlate with actual behaviors. This study is likely to provide valid estimates of public support for the study and of the study design factors that might influence participation, but is likely to be less accurate in estimating absolute participation rates. Additional research in existing genetic cohort studies would be needed to test these hypotheses.

Establishing the existence of wide public support for the proposed NIH cohort study is an important and necessary step, but will not be sufficient to launch such an ambitious project. Participating communities, public officials, and funders must believe that the study will return adequate benefits to its participants before they will allocate needed resources. Continued efforts to engage and involve the public in the planning and execution of this and other large cohort studies will help ensure that the research meets the wants and needs of participants to the greatest possible extent.

\section{ACKNOWLEDGMENTS}

This work was funded by the National Human Genome Research Institute under Grant number 1 U01 HG004206-0, Public Consultation to Inform the Design of Possible LargeScale Studies of Genes and Environment in Common Disease. The authors thank Jean McEwen of the Ethical, Legal and Social Implications (ELSI) Research Program at NHGRI, and Teri Manolio and Emily Harris of the Office of Population Genomics at NHGRI for their helpful discussions about survey design and data interpretation. The authors also thank the members of the Citizens Advisory Panel for their thoughtful input during the public engagement project. 


\section{References}

1. Watts G. UK biobank gets $10 \%$ response rate as it starts recruiting volunteers 2 . BM] 2007;334:659.

2. National Children's Study homepage. Available at: http://www.nationalchildrensstudy. gov/. Accessed June 18, 2008.

3. Roden D, Pulley J, Basford M, et al. Development of a large-scale de-identified DNA biobank to enable personalized medicine. Clin Pharmacol Ther 2008;84:362-369.

4. Kaiser Permanente Division of Research: research program on genes, environment, and health. Available at: http://www.dor.kaiser.org/studies/rpgeh/index.html. Accessed June 18, 2008.

5. Gulcher J, Stefansson K. Population genomics: laying the groundwork for genetic disease modeling and targeting 64. Clin Chem Lab Med 1998;36:523-527.

6. UK biobank homepage. Available at: http://www.ukbiobank.ac.uk/. Accessed June $18,2008$.

7. Palmer LJ. UK biobank: bank on it. Lancet 2007;369:1980-1982.

8. 23andMe launches consumer-enabled research program to actively engage individuals in genetics research. Available at: https://www.23andme.com/about/press/ 20080529/. Accessed June 25, 2008.

9. NHGRI National Institutes of Health. Design considerations for a potential United States population-based cohort to determine the relationships among genes, environment, and health: recommendations of an expert panel 519.

10. McQuillan GM, Pan Q, Porter KS. Consent for genetic research in a general population: an update on the National Health and Nutrition Examination Survey experience. Genet Med 2006:8 354-360.

11. Splansky GL, Corey D, Yang Q, et al. The third generation cohort of the National Heart, Lung, and Blood Institute's Framingham Heart Study: design, recruitment, and initial examination 190. Am J Epidemiol 2007;165:1328-1335.

12. Gulcher J, Stefansson K. An Icelandic saga on a centralized healthcare database and democratic decision making 171. Nat Biotechnol 1999;17:620.

13. North KE, Howard BV, Welty TK, et al. Genetic and environmental contributions to cardiovascular disease risk in American Indians: the strong heart family study. Am J Epidemiol 2003;157:303-314.

14. McQuillan GM, Porter KS, Agelli M, Kington R. Consent for genetic research in a general population: the NHANES experience. Genet Med 2003;5:35-42.

15. Manolio TA, Bailey-Wilson JE, Collins FS. Genes, environment and the value of prospective cohort studies. Nat Rev Genet 2006;7:812-820.

16. Collins FS, Manolio TA. Merging and emerging cohorts: necessary but not sufficient. Nature 2007;445:259.

17. Report of the first community consultation on the responsible collection and use of samples for genetic research. Available at: http://www.nigms.nih.gov/News/ Reports/community_consultation.htm. Accessed June 18, 2008.

18. Kaufman D, Geller G, LeRoy L, Murphy J, Scott J, Hudson K. Ethical implications of including children in a large biobank for genetic-epidemiologic research: a qualitative study of public opinion. Am J Med Genet C 2008;148C:31-39.

19. GPPC. Proposed study video. Available at: http://programs.dnapolicy.org/l/?l=937 Accessed July 1, 2008.

20. Validity of the survey of health and internet and Knowledge Network's panel and sampling. Available at: http://www.cdc.gov/PCD/issues/2004/oct/pdf/04_0004_01. pdf. Accessed July 1, 2008.

21. SPSS for Windows, rel. 16.0. Chicago, IL: SPSS Inc., 2008.

22. Statistics and social sciences: SUDAAN. Available at: http://www.nyu.edu/its/pubs/ connect/archives/98fall/yaffeesudaan.html. Accessed July 1, 2008.

23. SUDAAN version 9.0 online reference manual. Available at: http://www.rti.org/ sudaan/onlinehelp/flashhelp/wf_njs.htm. Accessed July 1, 2008.

24. Godard B, Marshall J, Laberge C. Community engagement in genetic research: results of the first public consultation for the Quebec CARTaGENE project. Community Genet 2007;10:147-158.

25. Hoeyer K, Olofsson BO, Mjorndal T, Lynoe N. Informed consent and biobanks: a population-based study of attitudes towards tissue donation for genetic research 85 . Scand J Public Health 2004;32:224-229.

26. Sigurdsson S. Decoding broken promises. openDemocracy. 2003. Available at: http://www.opendemocracy.net/theme_9-genes/article_1024.jsp. Accessed June 16, 2008.

27. Pulley JM, Brace MM, Bernard GR, Masys DR. Attitudes and perceptions of patients towards methods of establishing a DNA biobank. Cell Tissue Bank 2008;9:55-65.

28. Henderson G, Garrett J, Bussey-Jones J, Moloney ME, Blumenthal C, Corbie-Smith G. Great expectations: views of genetic research participants regarding current and future genetic studies. Genet Med 2008;10:193-200.

29. Wang SS, Fridinger F, Sheedy KM, Khoury MJ. Public attitudes regarding the donation and storage of blood specimens for genetic research. Community Genet 2001; $4: 18-26$.

30. Wong ML, Chia KS, Yam WM, Teodoro GR, Lau KW. Willingness to donate blood samples for genetic research: a survey from a community in Singapore. Clin Genet 2004;65:45-51.

31. Buchwald D, Mendoza-Jenkins V, Croy C, McGough H, Bezdek M, Spicer P. Attitudes of urban American Indians and Alaska Natives regarding participation in research. J Gen Intern Med 2006;21:648-651.

32. Halbert CH, Gandy OH Jr, Collier A, Shaker L. Intentions to participate in genetics research among African American smokers 142. Cancer Epidemiol Biomarkers Prev 2006;15:150-153.

33. Davis MD, Clark SJ, Singer DC, Tarini BA. Genetic testing and DNA biobanks-for whom, and when? National Poll on Children's Health C.S. Mott Children's Hospital; 2007;1:1.

34. Kettis-Lindblad A, Ring L, Viberth E, Hansson MG. Genetic research and donation of tissue samples to biobanks. What do potential sample donors in the Swedish general public think? Eur J Public Health 2006;16:433-440.

35. Chen DT, Rosenstein DL, Muthappan P, et al. Research with stored biological samples: what do research participants want? Arch Intern Med 2005;165:652-655.

36. McQuillan GM, Pan Q, Porter KS. Consent for genetic research in a general population: an update on the national health and nutrition examination survey experience. Genet Med 2006;8:354-360.

37. Malone T, Catalano PJ, O'Dwyer PJ, Giantonio B. High rate of consent to bank biological samples for future research: the Eastern cooperative oncology group experience. J Natl Cancer Inst 2002;94:769-771.

38. Wendler D, Emanuel E. The debate over research on stored biological samples: what do sources think? Arch Intern Med 2002;162:1457-1462.

39. Neidich AB, Joseph JW, Ober C, Ross LF. Empirical data about women's attitudes towards a hypothetical pediatric biobank. Am J Med Genet A 2008;146:297-304.

40. Moorman PG, Skinner CS, Evans JP, et al. Racial differences in enrolment in a cancer genetics registry. Cancer Epidemiol Biomarkers Prev 2004;13:1349-1354.

41. Howard BV, Devereux RB, Cole SA, et al. A genetic and epidemiologic study of cardiovascular disease in Alaska Natives (GOCADAN): design and methods. Int $J$ Circumpolar Health 2005;64:206-221.

42. Fernandez CV, Santor D, Weijer C, et al. The return of research results to participants: pilot questionnaire of adolescents and parents of children with cancer. Pediatr Blood Cancer 2007;48:441-446.

43. Clayton EW, Ross LF. Implications of disclosing individual results of clinical research. JAMA 2006;295:37.

44. Clayton EW. Informed consent and biobanks 254. J Law Med Ethics 2005;33:15-21.

45. National Bioethics Advisory Commission. Research involving human biological materials: ethical issues and policy guidance 573. Rockville, MD: National Bioethics Advisory Commission, 1999.

46. Navigenics homepage. Available at: http://www.navigenics.com. Accessed June 18 2008.

47. 23andMe-genetics just got personal. Available at: https://www.23andme.com/ ourservice/. Accessed June 18, 2008.

48. MacNeil SD, Fernandez CV. Attitudes of research ethics board chairs towards disclosure of research results to participants: results of a national survey. J Med Ethics 2007;33:549-553.

49. Partridge AH, Wong JS, Knudsen K, et al. Offering participants results of a clinical trial: sharing results of a negative study. Lancet 2005;365:963-964.

50. Goodson ML, Vernon BG. A study of public opinion on the use of tissue samples from living subjects for clinical research 106. J Clin Pathol 2004;57:135-138.

51. Kaphingst KA, Janoff JM, Harris LN, Emmons KM. Views of female breast cancer patients who donated biologic samples regarding storage and use of samples for genetic research. Clin Genet 2006;69:393-398.

52. McCarty CA, Nair A, Austin DM, Giampietro PF. Informed consent and subject motivation to participate in a large, population-based genomics study: the Marshfield Clinic personalized medicine research project. Community Genet 2007;10:2-9.

53. Hyun I. Fair payment or undue inducement? Nature 2006;442:629-630.

54. McGee G. A piece of my mind. Subject to payment? JAMA 1997;278:199-200.

55. Dunn LB, Gordon NE. Improving informed consent and enhancing recruitment for research by understanding economic behavior. JAMA 2005;293:609-612.

56. Creel AH, Losina E, Mandl LA, et al. An assessment of willingness to participate in a randomized trial of arthroscopic knee surgery in patients with osteoarthritis. Contemp Clin Trials 2005;26:169-178.

57. Halpern SD. Prospective preference assessment: a method to enhance the ethics and efficiency of randomized controlled trials. Control Clin Trials 2002;23:274-288.

58. Halpern SD, Karlawish JH, Casarett D, Berlin JA, Asch DA. Empirical assessment of whether moderate payments are undue or unjust inducements for participation in clinical trials. Arch Intern Med 2004;164:801-803.

59. Halpern SD, Karlawish JHT, Casarett D, Berlin JA, Townsend RR, Asch DA. Hypertensive patients' willingness to participate in placebo-controlled trials: implications for recruitment efficiency. Am Heart J 2003;146:985-992. 